\title{
Economic performance and inflation targeting in developing economies
}

\section{Olfa Manai Daboussi}

Higher Institute of Management, University of Tunis, Tunis

\section{Email address:}

manaolfa@yahoo.com

\section{To site this article:}

Olfa Manai Daboussi. Economic Performance and Inflation Targeting in Developing Economies. Journal of World Economic Research. Vol. 3, No. 1, 2014, pp. 1-7. doi: 10.11648/j.jwer.20140301.11

\begin{abstract}
This paper investigates the effect of inflation targeting (IT) on inflation, output growth and interest rates. Based on panel data of 53 developing countries, of which 20 that have adopted IT by the end of 2007. In this study we use the differences-in-differences approach of Ball and Sheridan (2005) to analyze the relationship between IT and economic performance over the period 1980-2012. The results show that the empirical analysis confirms that the effect of inflation targeting in developing economies will contribute effectively to achieve economic performance.
\end{abstract}

Keywords: Inflation Targeting, Developing Economies, Economic Performance

\section{Introduction}

Since the first adoption of inflation targeting (IT) by the Central Bank of New Zealand in 1990, the number of countries that have adopted this monetary regime has increased. Twenty-six Central Banks use inflation targeting as a framework for monetary policy, while others countries, mainly developing countries in preparing for the implementation of the new monetary regime.

Since the 1990's, the policy of inflation targeting is adopted as an alternative to policy to targeting monetary aggregates or exchange rate fixed. The absence of a clear theory of inflation targeting has made appear a very recent debate on the economic performance and the effectiveness of this policy in developing countries. The economists have explained theoretically targeting inflation only from 1995 (as Leiderman and Svensson (1995), Svensson (1997), Bernanke and Mishkin (1997) and Bernanke and al. (1999)).

During the last decade, inflation target was designed primarily to industrialized economies. These economies has experienced a periods of stability characterized by low inflation and sustainable economic growth. Thus economists have found that inflation targeting is an ideal setting for monetary policy. In fact, according to supporters of inflation targeting, the new framework for monetary policy increases transparency and strengthens the credibility of the Central Bank, which allows it to tackle the problem of time inconsistency ( Svensson (1997), Mishkin (1999), and Bernanke and al. (1999)).
Consequently, Corbo, Landerrache and Schmidt-Hebbel (2002) and Mishkin and Schmidt-Hebbel (2007) challenged the merits of IT namely its ability, among others, to attain the macroeconomic performance. However, these empirical evaluations in favor of the adoption of inflation targeting were in contradiction with the findings of Ducker and Fisher (1996) and Cecchetti and Ehrman (2000). They show that the stable level of inflation in industrialized and emerging countries is not due to the adoption of inflation targeting. They justify low inflation by a favorable global environment and the stability of inflation is observed in countries with inflation targeting and countries not adopting this monetary regime.

In this context, Pétursson (2004) and Genc et al. (2007) conclude that empirical validations are unable to justify the targeting inflation impact on the behavior of macroeconomic variables such as economic growth and inflation.

Other work, contradictory to these, like those of Da Silva and Portugal (2002), show that inflation targeting policy has an impact on the fluctuation of inflation.

Indeed, the implementation of the policy of inflation targeting seems more difficult in developing economies.

In practice, the results obtained in the majority of studies shows that the monetary authorities in the developing countries are less attached to their goals of price stability. Mishkin (2004) identified several characteristics of emerging 
countries that are the source of vulnerabilities, namely weak fiscal institutions and weak monetary institutions.

In the same context, Alberto and al. (2002) and Arminio and al. (2003) conducted an evaluation of the policy of inflation targeting in emerging economies. They checked that inflation is very volatile in these countries with a remarkable increase in the output. They argued that these results thus stem from more pronounced external shocks and lower credibility in these countries.

Based on the work of Ball and Sheridan (2005), the empirical results showed that the adoption of inflation targeting appears to have been irrelevant for a sample of twenty OECD countries (20 OCDE developed economies). Brito and Bystedt (2010) explore this method of Ball and Sheridan (2005) to conclude that despite the constraint of weak institution in emerging economies, policy of inflation targeting is effective. Indeed, in this literature review, we have tried to show the absence of a consensus on the issue of performance of the policy of inflation targeting. Thus, works are sometimes contradictory and represent empirical limits.

Based on these results, we try to establish an empirical approach that allows providing robust answers to show the effectiveness of inflation targeting in developing economies. The remainder of the paper is organized as follows: section two present the econometric methodology and introduces the dataset. Section three shows the estimation results. Section four is devoted to the discussion. Finally, we conclude.

\section{Econometric Methodology and Data}

Our objective is to determine how inflation targeting affects dimensions of economic performance such as inflation, output growth and interest rates.

In fact, to evaluate the effect of inflation targeting, inflation, volatility of inflation, output growth, output growth volatility and interest rates, we use the approach of Ball and Sheridan (2005) by extending a standard differences-in-differences approach. First, this approach managed to avoid the selection bias. Second, it examines the effect of certain treatment (like adoption of inflation targeting) on a variable through comparing the treatment group after treatment to the treatment group before treatment and a control group. The untreated control group represents what would have happened in the absence of the treatment.

We run the regression:

$$
X_{i t}=k+a_{1} Q_{i t}+\mu_{t}+\eta_{t}+v_{i t}
$$

We are interested in estimating the effect of inflation targeting on a certain economic variable $\mathrm{X}$.

Let $X_{i t}$ be the value of $X$ in country $i$ and period $t$. the $t$ subscript takes on two values, pre and post targeting level.
Where $\mathrm{k}$ is a constant, $\mathrm{Q}_{\mathrm{it}}$ a dummy variable ${ }^{1}$ equal to unity if country $i$ targets inflation and zero otherwise, $\mu_{t}$ and $\eta_{t}$ respectively capture the country and specific effects, $v_{i t}$ is the error term.

Equation (1), the $\mathrm{Q}_{\mathrm{it}}$ term captures the possible effect on inflation targeting. We would like to estimate its coefficients, $a_{1}$. Differencing equation (1) over time yields

$$
\begin{aligned}
& X_{i, \text { post }}-X_{i, \text { pre }}=\eta_{\text {post }}+a_{1} Q_{i, \text { post }}+\mu_{t}+v_{i, \text { post }}-\left(\eta_{\text {pre }}+a_{1} Q_{i, \text { pre }}+\mu_{t}+v_{i \text { pre }}\right) \\
& X_{i, \text { post }}-X_{i, \text { pre }}=\left(\eta_{\text {post }}-\eta_{\text {pre }}\right)+a_{1}\left(Q_{i \text { post }}+Q_{i p r s}\right)+\left(v_{i, \text { post }}-v_{i, p r a}\right)(2)
\end{aligned}
$$

This can be interpreted as an OLS estimator as follows.

$$
\mathrm{X}_{\mathrm{i}, \text { post }}-\mathrm{Xi}, \text { pre }=\mathrm{a}_{0}+\mathrm{a}_{1} \mathrm{D}_{\mathrm{i}}+\mathrm{e}
$$

We use the fact that $\mathrm{Q}_{\mathrm{i} \text {, post }}-\mathrm{Q}_{\mathrm{i} \text {, pre }}=\mathrm{D}_{\mathrm{i}}$. Thus, in cross country data, the change in $X$ depends on a constant $\left(\eta_{\text {post }}\right.$ $\left.\eta_{\text {pre }}\right)$, the targeting dummy, and a composite error term.

We can rewrite equation (2) as

$X_{i, \text { post }}-X_{i, \text { pre }}=\left(\eta_{\text {post }}-\eta_{\text {pre }}\right)+a_{1} D_{i}+a_{2} X_{i}$, pre $+\left(v_{i, \text { post }}-v_{i, \text { pre }}\right)$

Where

$$
X_{i, \text { post }}-X_{i, \text { pre }}=a_{0}+a_{1} D_{i}+a_{2} X_{i} \text {, pre }+e
$$

This equation can be estimate through the OLS method. The coefficient on the dummy shows targeting affects a country's change in performance for a given initial performance. $X_{i \text {, pre }}$ is a dependent variable that allows us to control whether inflation targeting had, an average, initial higher levels of inflation. Thus we avoid out of proportion estimates due to a sharp downward change in absolute terms. Then, this describes the countries in our sample and the inflation targeting and non targeting periods that we examine. Our sample includes 53 developing economies.

To test the effect of inflation targeting on economic performance, we evaluate its effect on inflation, output growth and their volatilities and interest rates. In this work, the focus will be on the developing countries, because empirical studies dealing the case of these economies are rare and the results are sometimes contradictory.

\subsection{Data}

Our dataset consists of 53 developing countries examined over the period 1980-2012. The sample is composed of $20^{2}$ developing countries that have adopted IT by the end of 2007 (called ITers or treatment group) and 33 non ITers $^{3}$ (or control group) (see table A in appendix). For

\footnotetext{
${ }^{1}$ For all countries, $\mathrm{Q}_{\mathrm{i}}$, pre equal zero and for inflation targeters $\mathrm{Q}$, post equals one (equal $\mathrm{D}_{\mathrm{i}}$, the targeting dummy in the text).

2 Inflation targeting countries: Brazil, Poland, Chile, Romania, Colombia, Slovakia, Czech Republic, South Africa, Guatemala, South Korea, Hungary, Thailand, Indonesia, Turkey, Israel, Serbia, Mexico, Ghana, Peru, Philippines.

${ }^{3}$ Group of non inflation targeters is composed by: Algeria, Georgia, Morocco, Argentina, Hong Kong, Paraguay, Belarus, Iran, Russia, Bulgaria, Jamaica, Singapore, Cape Verde, Jordan, Slovenia, China, Kazakhstan, Syria, Costa Rica,
} 
purpose of comparability, our sample relies on Lin and Ye (2009) and Roger (2009). The developing countries category considered here refers to the World Bank classification, thus includes both low-income countries and emerging-market countries. Accordingly, we estimate treatment effect of IT upon macroeconomics variables by the chosen conservative starting dates of IT. Because effect of IT upon our variables is driven by the chosen starting dates of IT (see table B in appendix).

We employ inflation that is measured as quarterly percentage change in the Consumer Price Index (CPI), GDP growth rates and interest rates from the IMF's International Financial Statistics (IFS). We estimate the average volatility of inflation and output growth ${ }^{4}$.

For robustness reason, we adopt two different periods (pre-targeting periods and post-targeting periods). It has been defined and represented in table $\mathrm{C}$ in appendix. The first sample starts in the first quarter of 1980 and ends before a period of the implementation of inflation targeting. The second is a post-targeting sample; this period begins on the date of adoption and ends in the second quarter of 2012.

However, the delimitation of periods remains fairly tedious to implement for countries not adopting inflation targeting. Ball and Sheridan (2005) consider the end date of the pre-inflation targeting as the average dates of adoption of this monetary regime by other countries actually adopting inflation targeting table.

Indeed, representative adaptation date for non-inflation targeting countries is 1999 , which is the mean year of when inflation targeting was adopted in developing countries. Table B in appendix, represent a starting date of inflation targeting framework in developing countries. The study sample includes developing countries that have experienced hyperinflation; we prepare estimates by adjusting the inflation to $50 \%$ in years when inflation was above $50 \%$.

\section{Estimation Results}

\subsection{Effect on Inflation}

In table 1, we represent the main results of these estimations, namely, the developing economies adopting IT regime saw more significant reductions in average inflation then those that selected alternative framework to conduct their monetary policies. The dummy variable in the inflation regressions is of negative sign. Average inflation decreased by 3.62 to 2.5 percent between the periods before and after targeting inflation targeting.

Then, we substitute inflation volatility for average of inflation in regression of equation (4) during the different sample periods for all developing economies.

Latvia, Trinidad and Tobago, Croatia, Lebanon, Tunisia, Dominican Republic, Lithuania, Ukraine, Egypt, Macedonia, Uruguay, Estonia, Mauritius and Venezuela.

${ }^{4}$ The volatility of inflation or output growth is calculated as the standard deviation from the average.
Table 1. Estimation of average inflation. Dependent variable: Change in mean inflation between samples.

\begin{tabular}{lll}
\hline & Before IT regime & After IT regime \\
\hline IT Dummy & $-3.62 * *(1.61)$ & $-2.5 * * *(1.07)$ \\
Initial mean & $-1.12 *(0.31)$ & $-0.91 *(1.07)$ \\
Constant & $5.62 *(1.31)$ & $3.4 *(0.87)$ \\
$\mathrm{R}^{2}$ & 0.96 & 0.92 \\
Observations & 53 & 53 \\
\hline
\end{tabular}

Note: $* * * * * *$ respectively denote significance at the $1 \%, 5 \%$ and $10 \%$ levels.

Standard errors within parenthesis.

The results of the estimates in table 2 , show a decline in inflation volatility in countries adopting inflation targeting, while this decline seems to be interrupted in countries that do not adopt inflation targeting.

Table 2. Estimation of inflation volatility. Dependent variable: Change in the standard deviation of inflation between samples.

\begin{tabular}{lll}
\hline & Before IT regime & After IT regime \\
\hline IT Dummy & $-3.98^{*}(0.97)$ & $-3.07 * *(1.12)$ \\
Initial mean & $-0.54 * *(0.71)$ & $-0.76^{* *}(1.12)$ \\
Constant & $5.62 *(0.71)$ & $2.5 *(0.98)$ \\
$\mathrm{R}^{2}$ & 0.86 & 0.67 \\
Observations & 53 & 53 \\
\hline
\end{tabular}

Note: $* * * * * *$ respectively denote significance at the $1 \%, 5 \%$ and $10 \%$ levels.

Standard errors within parenthesis

\subsection{Effect on Growth}

We use the same method above to test the effect of inflation targeting on economic growth. The estimates in table 3 , show that IT dummy appears significant and with negative sign during two periods. These results show that inflation targeting has caused lower average growth.

Table 3. Estimation of average output growth. Dependent variable: Change in mean annual growth rate between samples.

\begin{tabular}{lll}
\hline & Before IT regime & After IT regime \\
\hline IT Dummy & $-2.23 * * *(1.01)$ & $-0.5 * * *(0.07)$ \\
Initial mean & $-1.62 *(0.95)$ & $-1.5 *(0.87)$ \\
Constant & $4.62 *(0.31)$ & $3.5 *(0.07)$ \\
$\mathrm{R}^{2}$ & 0.75 & 0.59 \\
Observations & 53 & 53 \\
\hline
\end{tabular}

Note: $* * *, * * *$ respectively denote significance at the $1 \%, 5 \%$ and $10 \%$ levels.

Standard errors within parenthesis

Now, we estimate growth volatility. Estimation results in table 4 , show that IT dummy appears with a negative sign and no significant. Thus, it appears that inflation targeting reduces growth rates and it creates a less stable economic growth. This shows that countries adopting inflation 
targeting are able to deal with various shocks affecting their economic structures.

Table 4. Estimation of output growth volatility. Dependent variable: Change in the standard deviation of growth rate between samples

\begin{tabular}{lll}
\hline & Before IT regime & After IT regime \\
\hline IT Dummy & $-1.62(1.51)$ & $-0.85(1.07)$ \\
Initial mean & $-3.62^{* * *}(1.31)$ & $-2.5^{* *}(0.21)$ \\
Constant & $0.62^{* *}(0.31)$ & $0.94^{*}(0.52)$ \\
$\mathrm{R}^{2}$ & 0.43 & 0.29 \\
Observations & 53 & 53 \\
\hline
\end{tabular}

Note: $* * *, * * *$ respectively denote significance at the $1 \%, 5 \%$ and $10 \%$ levels.

Standard errors within parenthesis.

We can conclude that the choice of inflation targeting in developing countries has helped to reduce inflation. These results are consistent with those of Gonçalves and Salles (2006), which suggests that the choice of an inflation targeting regime is beneficial in a group of 36 emerging countries.

\subsection{Effect on Interest Rates}

We examine now the variability of short-term interest rates, which could inform us about the role of Central Banks in the conduct of monetary policy, particularly in the use of monetary instruments.

As the method of Ball and Sheridan (2005), we examine the standard deviation of short-term rates, because this statistic is sensitive to the detection of changes in monetary policy rules. In fact, if the authorities respond more strongly to changes in inflation, interest rates in the shortterm should be more volatile. We begin our estimates from 1990, due to unavailability of some data before this date.

The results in Table 5, show that the interest rate is low volatility in countries with non-targeting $\left(\mathrm{R}^{2}=0.28\right)$ during the period before targeting. Whereas, for countries targeting, inflation volatility is high and justified by the significance of the coefficients.

Table 5. Estimation of interest rates volatility. Change in the standard deviation of the short term interest rate between samples.

\begin{tabular}{lll}
\hline & Before IT regime & After IT regime \\
\hline IT Dummy & $-0.62(0.31)$ & $-0.34^{* *}(0.27)$ \\
Initial mean & $-0.72(0.41)$ & $-0.58(0.36)$ \\
Constant & $2.65(0.21)$ & $2.33(0.26)$ \\
$\mathrm{R}^{2}$ & 0.68 & 0.73 \\
Observations & 53 & 53 \\
\hline
\end{tabular}

Note: $* * *, * * *$ respectively denote significance at the $1 \%, 5 \%$ and $10 \%$ levels.

Standard errors within parenthesis

In fact, we find that IT improves a country's economic performance particularly in developing countries. Then, through this study, the results suggest that inflation targeting changes the behavior of the monetary authorities in the handling of their instruments. This new monetary regime is beneficial to economic performance. In addition, developing countries must meet macroeconomic, financial and institutional conditions for the implementation of a strategy of inflation targeting.

\section{Discussion}

The purpose of this paper was to evaluate the effectiveness of the policy of inflation targeting. This topic has been the subject of many economic debates. In our study, we have tried to provide some robust answers to some ambiguous question so far.

Based on various studies, we proposed a very recent approach in the economic literature: the method of differences-in-differences of Ball and Sheridan (2005).

We have shown that inflation targeting is relevant for developing economies. This same method was used by the same economists in the case of 20 OECD countries but the results are totally contradictory.

Our work has shown short comings. The regime of inflation targeting based on certain institutional conditions (such as the independence of the Central Bank and solid performance systems, and stable economic structures (Pétursson (2009)) and Hove (2010)).

However, our work is inspired from the model of Ball and Sheridan (2005) and Mishkin and Schmidt-Hebbel (2007) to compare the effect of inflation targeting in developing countries (adopting inflation targeting and those not adopting this monetary policy). The choice of macroeconomic variables is limited to the volatility of inflation, the rate of economic growth and the short-term interest rates. Other studies, (Kim and Beladi (2009) and Sachsida and al. (2003) and Al-Nasser and al. (2009), have taken into account the commercial independence of developing countries relative to the rest of the world which identifies the ability of the policy of inflation targeting to control the price change. Therefore, the choice of monetary policy becomes dependent on the degree of openness of the economy and the nature of the shocks.

The analysis of economic developments using this method in the case of developing countries lacks precision. Our methodology has not shown that the adoption of inflation targeting positively affects the dynamics of inflation. A new method is proposed, this is the method of evolutionary spectral analysis has been used by Ftiti.Z and Essadi.E (2013). This method is used to model inflation in a sample of four developed countries adopting inflation targeting. It can detect structural breaks in the series of inflation and which coincide with the economic facts (Ben Aissa, Boutahar and Jouini (2004)).

Thus, to address the same matter of the volatility of inflation and economic growth, we can use the postulates developed by Pétursson (2005) and Batini and Laxton (2007). These studies show the positive impact of the adoption of inflation targeting on economic performance. 
Thus, using the method Hyvonen (2004) or Vega and Winkelried (2005) remain an opportunity in the economic literature, because it shows that the volatility of inflation has declined with inflation targeting whereas economic growth has increased.

Indeed, our empirical analysis could be further developed taking into account institutional factors. The legal independence of the Central Bank can inform us about the credibility and transparency of the Central Bank and its role in controlling the volatility of inflation.

This study can be extended by studying other samples from different geographic areas. We can treat the case, for example, of the countries of Eastern Europe and Asian countries in order to have a more significant effect in our estimates.

\section{Conclusion}

The results suggest that the choice of an inflation targeting regime is beneficial for developing economies. The results for average inflation and inflation volatility are in favor of IT. Countries that have adopted inflation targeting have experienced significant volatility of economic growth, that

which show the challenge of monetary policy to confront effect of shocks in their economies. However, the results regarding growth volatility are sometimes ambiguous; because both empirical evidence show that the inflation targeting regime hampers economic growth.

In sum, the results suggest that the effect of inflation targeting in developing economies will contribute effectively to achieve economic performance. This effect seems to be a temporary phenomenon. In addition, the study of the effect of inflation targeting in developing countries must take into account effects of institutional and economic and social development in these economies. Indeed, most economists who have dealt inflation targeting in developing economies suggests that improved economic performance under inflation targeting requires a high level of transparency and communication with the public and the development of financial institutions. They propose a procedure that a Central Bank under inflation targeting can apply and communicate when facing strong supply shocks. In addition, they suggest a monitoring structure for an inflation targeting regime under and IMF program.

\section{Appendix}

Table A. Country list.

\begin{tabular}{|c|c|c|c|c|}
\hline Treatment group & & Control group & & \\
\hline Brazil & Poland & Algeria & Georgia & Morocco \\
\hline Chile & Romania & Argentina & Hong kong & Paraguay \\
\hline Colombia & Slovakia & Belarus & Iran & Russia \\
\hline Czech Republic & South Africa & Bulgaria & Jamaica & Singapore \\
\hline Guatemala & South Korea & Cape Verde & Jordan & Slovenia \\
\hline Hungary & Thailand & China & Kazakhstan & Syria \\
\hline Indonesia & Turkey & Costa Rica & Latvia & Trinidad and Tobago \\
\hline Israel & Serbia & Croatia & Lebanon & Tunisia \\
\hline Mexico & Ghana & Dominican Republic & Lithuania & Ukraine \\
\hline Peru & & Egypt & Macedonia & Uruguay \\
\hline Philippines & & Estonia & Mauritius & Venezuela \\
\hline
\end{tabular}

Source: Lin and Ye (2009) and Roger (2009). Serbia and Ghana are two countries are absent in Lin and Ye 2009's sample.

Table B. Developing inflation targeters along with their starting dates.

\begin{tabular}{lll}
\hline & $\begin{array}{l}\text { Soft IT: Default } \\
\text { starting dates }\end{array}$ & $\begin{array}{l}\text { Full Fledged IT: } \\
\text { Conservative starting dates }\end{array}$ \\
\hline Chile & January 1991 & August 1999 \\
Israel & January 1992 & June 1997 \\
Czech Republic & January 1998 & January 1998 \\
South Korea & April 1998 & April 1998 \\
Poland & September 1998 & September 1998 \\
Mexico & January 1999 & January 2001 \\
Brazil & June 1999 & June 1999 \\
Colombia & September 1999 & October 1999 \\
Philippines & January 2002 & January 2002 \\
South Africa & February 2000 & February 2000 \\
Thailand & May 2000 & May 2000 \\
\hline
\end{tabular}

\begin{tabular}{lll}
\hline & $\begin{array}{l}\text { Soft IT: Default } \\
\text { starting dates }\end{array}$ & $\begin{array}{l}\text { Full Fledged IT: } \\
\text { Conservative starting dates }\end{array}$ \\
\hline Hungary & June 2001 & August 2001 \\
Peru & January 2002 & January 2002 \\
Slovakia & January 2005 & January 2005 \\
Guatemala & January 2005 & January 2005 \\
Indonesia & July 2005 & July 2005 \\
Romania & August 2005 & August 2005 \\
Turkey & January 2006 & January 2006 \\
Serbia & September 2006 & September 2006 \\
Ghana & January 2007 & January 2007 \\
\hline
\end{tabular}

Source: Rose (2007) and Roger (2009). Note that Slovakia abandoned IT in 2009 and joined the Euro Area. 
Table C. Sample periods for estimation method of Ball and Sheridan (2005).

\begin{tabular}{|c|c|c|}
\hline Inflation targeting* & Pre-Period & Post-period \\
\hline Chile & 1980:1-1999:2 & 1999:3-2012:2 \\
\hline Israel & 1980:1-1997:2 & $1997: 3-2012: 2$ \\
\hline Czech Republic & 1980:1-1997:4 & 1998:1-2012:2 \\
\hline South Korea & 1980:1-1998:1 & $1998: 2-2012: 2$ \\
\hline Poland & 1980:1-1998:2 & 1998:3-2012:2 \\
\hline Mexico & 1980:1-1999:4 & 2000:1-2012:2 \\
\hline Brazil & 1980:1-1999:2 & 1999:3-2012:2 \\
\hline Colombia & 1980:1-1999:3 & 1999:4-2012:2 \\
\hline Philippines & 1980:1-2001:4 & 2002:1-2012:2 \\
\hline South Africa & 1980:1-1999:4 & 2000:1-2012:2 \\
\hline Thailand & 1980:1-2000:1 & $2000: 2-2012: 2$ \\
\hline Hungary & 1980:1-2001:2 & $2001: 3-2012: 2$ \\
\hline Peru & 1980:1-2001:4 & 2002:1-2012:2 \\
\hline Slovakia & 1980:1-2004:4 & 2005:1-2012:2 \\
\hline Guatemala & 1980:1-2004:4 & 2005:1-2012:2 \\
\hline Indonesia & $1980: 1-2005: 2$ & 2005:3-2012:2 \\
\hline Romania & 1980:1-2005:2 & $2005: 3-2012: 2$ \\
\hline Turkey & 1980:1-2006:2 & $2006: 3-2012: 2$ \\
\hline Serbia & 1980:1-2006:3 & 2006:4-2012:2 \\
\hline Ghana & 1980:1-2006:4 & 2007:1-2012:2 \\
\hline \multicolumn{3}{|c|}{ Non-inflation targeting $* * *$} \\
\hline Average date** & 1980:1-2001:2 & $2001: 3-2012: 2$ \\
\hline
\end{tabular}

Source: **Authors' calculation. * Roger (2009).

*** The group of non inflation targeters is composed by: Algeria, Georgia, Morocco, Argentina Hong Kong, Paraguay, Belarus, Iran, Russia, Bulgaria, Jamaica, Singapore, Cape Verde, Jordan Slovenia, China, Kazakhstan, Syria, Costa Rica, Latvia, Trinidad and Tobago, Croatia, Lebanon Tunisia, Dominican Republic, Lithuania, Ukraine, Egypt, Macedonia, Uruguay, Estonia Mauritius and Venezuela.

JEL Classification Numbers: E31, E52, E58.

\section{References}

[1] Alberto and al. (2002). Inflation Targeting in Emerging Market Countries, Too Much Exchange Rate Intervention? A Test Goldman Sachs Economic Research.

[2] Al-Nasser, O. M., Sachsida, A. and Mário, M. (2009). The Openness Inflation Puzzle: Panel Data Evidence. International Research Journal of Finance and Economics, 28, 169-181.

[3] Armand, F. A. and S, Roger. (2013). Inflation Targeting and Country Risk: an Empirical Investigation. IMF/WP/13/21.

[4] Amato, J.D. and Gerlach, S. (2002). Inflation Targeting in Emerging Market and Transition Economies: Lessons after a decade. European Economic Review, 46(4-5), 781-790.

[5] Arminio, F. Ilan, G. and Andre, M. (2003). Inflation Targeting in Emerging Market. NBER, WP/ 10019.

[6] Ball, L. and N. Sheridan. (2005). Does Inflation Targeting
Matter?, In The Inflation Targeting Debate, edited by B. S. Bernanke and M. Woodford, 249-76. University of Chicago Press for the NBER.

[7] Batini, N., and D. Laxton. (2007). Under What Conditions Can Inflation Targeting be Adopted?, in F. S. Mishkin and K. Schmidt-Hebbel (eds), Monetary Policy Under Inflation Targeting, Santiago, Banco Central de Chile: Santiago, 467506.

[8] Ben Aissa M.S., Boutahar M., and Jouini J. (2004). The Bai and Perron's and Spectral Density Methods for Structural Change Detection in the US Inflation Process, Applied Economics Letters, 11, 2, pp. 109-115.

[9] Bernanke, B., and F. S. Mishkin. (1997). Inflation Targeting: A New Framework for Monetary Policy, Journal of Economic Perspectives, 11(2), 97-116.

[10] Bernanke, S., Laubach, T., Mishkin, F. and Posen, A.S (1999). Inflation Targeting: Lessons from The International experience (Princeton University Press).

[11] Brito, R.D. and Bystedt, B. (2010). Inflation Targeting in emerging economies: Panel evidence. Journal of Development Economics, 91(2), 198-210.

[12] Cecchetti, S. and Ehrmann, M. (2000). Does Inflation Targeting Increase Output Volatility? An International Comparison of Policy Maker's Preferences and Outcomes. Central Bank of Chile, 69.

[13] Corbo, C.,C. Landarretche, M. and K. Schmidt-Hebbel. (2002). Does Inflation Targeting Make a Difference?, in N. Loayza and R. Soto (eds), Inflation Targeting: Design, Performance, Challenges, Central Bank of Chile: Santiago, 221-69.

[14] Da Silva M.E.A, Portugal M. (2002). Inflation Targeting in Brazil: An empirical Evaluation, Revista de Economia, 9, 2, pp. 85-122.

[15] Divino, J. A. (2009). The Impact of Inflation Targeting on Unemployment in Developing and Emerging Markets. International Policy Centre for Inclusive Growth, WP. 56.

[16] Fischer, S. (1993). The Role of Macroeconomic Factors in Growth. Journal of Monetary Economics, 32, 5, 455-511.

[17] Ftiti.Z and Essadi. E (2013). Relevance of the Inflation Targeting Policy. Journal of Economic and Financial Modelling. Vol.1 No.1, pp. 62-72.

[18] Kim, M. and Beladi, H. (2009). Is Free Trade Deflationary? Economics Letters, 89(3), pp. 343-349.

[19] Genc I.H., Lee M., Rodriguez C.O., Lutz S. (2007). Time Series Analysis on Inflation Targeting in Selected Countries. Journal of Economic Policy Reform, 10, 1,15-27.

[20] Gonçalves, C.E.S., Salles, J.M. (2008). Inflation Targeting in Emerging Economies: What do the Data Say? Journal of Development Economics, 85(1-2), 312-318.

[21] Hove, S. (2010). Do Institutional Structures Really Matter for Inflation Targeting in Emerging Market Economies? School of Economics, University of Cape Town WP.

[22] Hyvonen, M. (2004). Inflation Convergence Across Countries. Discussion Paper 2004-04. Sydney: Reserve 
Bank of Australia.

[23] Leiderman, L. and Svensson, Lars E.O. (1995). Inflation Targets. London: Centre for Economic Policy Research.

[24] Levin, A. T., F. M. Natalucci and J. M. Piger. (2004). The Macroeconomic Effects of Inflation Targeting. Federal Reserve Bank of St. Louis Review, 86(4), 51-80.

[25] Lin, S. (2010). On the International Effects of Inflation Targeting. The Review of Economics and Statistics, 92(1), 195-99.

[26] Lin, S. and Ye, H. (2009). Does Inflation Targeting Make a Difference in Developing Countries?. Journal of Development Economics, 89(1), 118-123.

[27] Manai, O. Chebbi, A. and Madouri, A. (2013). Inflation Targeting Policy: Pre-Requisites and Opportunities for Tunisia. Science Journal of Economics. Doi 10.7237/Sje/234. Vol 2013.

[28] Mishkin, F.S. (1999). International Experiences with Different Monetary Policy Regimes. Journal of Monetary Economics, 43, 3, 579-606.

[29] Mishkin, F.S. (2000). Inflation Targeting in Emerging Market Countries. American Economic Review, 90 (2), $105-109$.

[30] Mishkin, F. S. (2004). Can Inflation Targeting Work in Emerging Market Countries?. NBER, WP.10646.

[31] Mishkin, F. (2007). Monetary Policy Under Inflation Targeting: An Introduction. WP, Central Bank of Chile, 396.

[32] Mishkin, F.S., Schmidt-Hebbel, K. (2007). Does Inflation Targeting Make a Difference?. NBER. WP.12876.

[33] Mollick, V., Torres, R. and Carneiro, F. (2008). Does
Inflation Targeting Matter for Output Growth?. Evidence from Industrial and Emerging Economies. World Bank WP. 4791.

[34] Pétursson, T. (2004. The Effects of Inflation Targeting on Macroeconomic Performance. Central Bank of Iceland, WP. 23.

[35] Pétursson, T. (2009). Inflation Control Qround the World: Why are some Countries More Successful than Others? Central Bank of Iceland.

[36] Rose, A. K. (2007). A Stable International Monetary System Emerges: Bretton Woods, Reversed. Journal of International Money and Finance, 26(5), 663-81.

[37] Roger, S. (2009). Inflation Targeting at 20: Achievements and Challenges. IMF WP/09/236. Schmidt-Hebbel, K. and

[38] Sachsida, A., Carneiro, F. and Loureiro, Paulo R. A. (2003). Does Greater Trade Openness Reduce Inflation?. Further Evidence Using Panel Data Techniques. Economics Letters, 81, pp. 315-319.

[39] Svensson, L.E.O. (1997). Inflation Targeting in an Open Economy: Strict or Flexible Inflation Targeting ?. European Economic Review, 41, p. 111 "U1146.

[40] Truman, E.M.. (2003). Inflation Targeting in the World Economy. Institute for International Economics, Washington DC.

[41] Vega, M., Winkelried, D. (2005). Inflation Targeting and Inflation Behavior: A Successful Story?. International Journal of Central Banking, 1(3), 153-175.

[42] Wu, T. (2004). Does Inflation Targeting Reduce Inflation?. An Analysis for the OECD Industrial Countries, Banco Central do Brazil, WP. 83. 